22

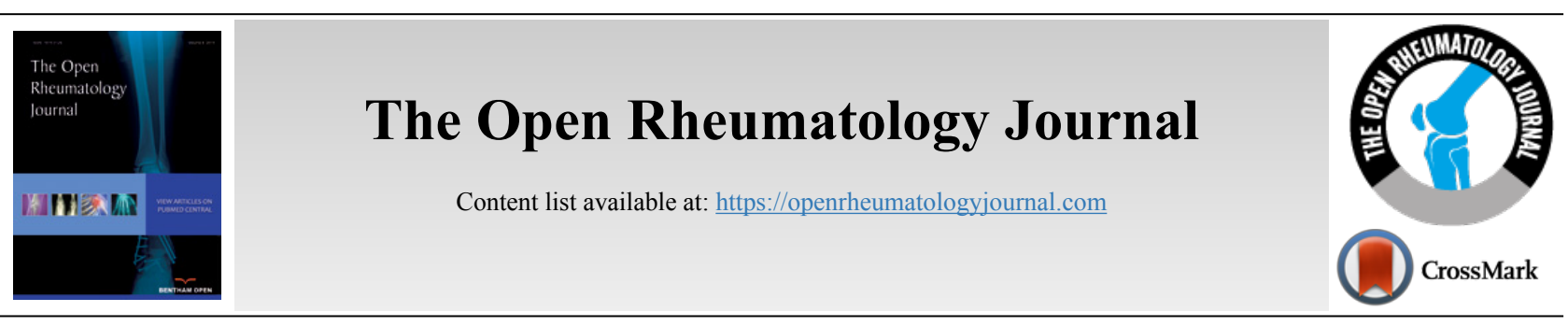

RESEARCH ARTICLE

\title{
Bone Mineral Density and Bone Remodeling in Tunisian Patients with Inflammatory Bowel Disease
}

Samar Ben Jemaa ${ }^{1, *}$, Lassaad Chtourou ${ }^{2}$, Rim Akrout ${ }^{1}$, Khansa Chaabouni ${ }^{3}$, Tarek Chaabouni ${ }^{3}$, Hela Makni Fourati ${ }^{1}$, Ali Amouri $^{2}$, Nabil Tahri ${ }^{2}$, Fatma Ayedi ${ }^{3}$ and Sofien Baklouti ${ }^{1}$

${ }^{1}$ Department of Rhumatology, Hedi Chaker University Hospital, Sfax, Tunisia

${ }^{2}$ Department of Gastroenterology and Hepatology, Hedi Chaker University Hospital, Sfax, Tunisia

${ }^{3}$ Laboratory of Biochemistry, Habib Bourguiba University Hospital, Sfax, Tunisia

\begin{abstract}
:
Background:

A high prevalence of osteopenia and osteoporosis is observed in patients with Inflammatory Bowel Disease (IBD).

Objective:

The aim of our study was to investigate the prevalence of bone loss, bone remodeling and risk factors in Tunisian patient with IBD.

Patients and Methods:

The study included 40 patients with IBD and 32 age- and sex-matched healthy controls subjects. All participants underwent bone densitometry by dual energy X-ray absorptiometry at the femoral neck and lumbar spine. Serum levels of 25-hydroxy vitamin D (25(OH)D), parathyroid hormone $(\mathrm{PTH})$, osteocalcin $(\mathrm{OC})$, and urinary degradation products of C-terminal telopeptide of type I collagen (CTXI) were measured in all participants to assess the bone metabolism status.

Results:

Twelve (30\%) patients were normal, $32.5 \%$ were osteopenic and $37.5 \%$ were osteoporotic. Osteoporosis was more frequent in IBD patients than controls $(\mathrm{p}=0.0001)$. Age and inflammation were associated with low bone mineral density (BMD). Mean calcium, phosphorus and alkaline phosphatase levels were similar in both groups. Median $25(\mathrm{OH})$ D levels were significantly lower in IBD patients compared with controls $(\mathrm{p}=0.0001)$. Median urinary CTXI levels were significantly higher in IBD patients compared with healthy controls $(\mathrm{p}=0.007)$. No significant differences between IBD patients and controls concerning the median serum OC and PTH levels were found.

Conclusion:

In our study, there is a high prevalence of low BMD in IBD patients and an increase in bone resorption without a change of bone formation. Low $\mathrm{BMI}$ and hypovitaminoses D were identified as risk factors for low BMD.
\end{abstract}

Keywords: Inflammatory bowel disease, Osteopenia, Osteoporosis, Hypovitaminosis D, Bone mineral density, Bone remodeling.

\begin{tabular}{ll|l|r} 
Article History & Received: November 30, 2018 & Revised: January 31, 2019 & Accepted: February 18, 2019
\end{tabular}

\section{INTRODUCTION}

There is a growing body of evidence that patients with Inflammatory Bowel Disease (IBD) are at increased risk for osteopenia and osteoporosis. Osteopenia and osteoporosis are common extraintestinal complications in IBD that increase the

\footnotetext{
* Address correspondence to this author at the Department of Rhumatology, Hedi Chaker University Hospital, Sfax, PC: 3089, Tunisia; Tel: 23733004;
}

E-mail: bendjmaa@gmail.com risk of vertebral and femoral neck fractures $[1,2]$.

The prevalence of osteoporosis is changeable depending on the studied population and the technique of bone density measurement used [3]. Certain factors are related to the disease itself (intestinal inflammation, extent of lesions, disease duration), whereas others depend on the patient himself (age, body mass index, nutritional status, hormonal status) or the treatment (corticosteroids or surgical resection) [1, 2]. 
Several studies have demonstrated a decrease in Bone Mineral Density (BMD) in patients with Crohn's Disease (CD), and to a less extent in Ulcerative Colitis (UC) [4]. The higher prevalence of bone disease in $\mathrm{CD}$ patients is thought to be related to ileal and small intestine involvement of diseasecausing vitamin $\mathrm{D}$ and calcium malabsorption, estrogen deficiency and malnutrition $[1,5]$. However, some recent studies have found no significant differences in the prevalence of osteoporosis between patients with UC and those with $\mathrm{CD}$ $[6,7]$.

Bone tissue is constantly being renewed and repaired by a coupled process of resorption and formation called bone remodeling. In this study, we aimed to estimate the prevalence of bone loss and the rate of bone remodeling in Tunisian adults patients with IBD, and identify the potential risk factors of bone loss.

\section{PATIENTS AND METHODS}

\subsection{Patients}

This is a single-centre clinical cross-sectional and comparative study, conducted between October 2013 and June 2014. In this period, forty IBD patients who followed up at the Department of Gastroenterology and Rheumatology at Hedi Chaker University Hospital were included in this study. Our study received research ethics board approval from the "C.P.P. SUD” (0069/2018) committee. Thirty two age- and sexmatched healthy subjects were selected as controls. All participants, patients and controls, were of Tunisian origin.

The exclusion criteria of the study included diseases known to affect bone metabolism such as malignant diseases, celiac disease, short bowel disease, kidney failure, liver disease, thyroid disease, diabetes mellitus and the use of medications such as bisphosphonates, sodium fluoride, calcitonin and hormone substitution therapy.

The diagnosis of UC and CD was based on standard criteria including clinical criteria, endoscopy and histopathological biopsy $[8,9]$ and the Montreal classification was used for disease phenotyping [10]. The activity and severity of diseases were evaluated based on the Crohn's disease activity index (CDAI) for CD and the Truelove-Witts score for UC [11, 12].

For each patient, the following data were collected: age, gender, menopausal status for females, smoking status, physical activity, solar index (number of hours of sun exposition X exposed part of the body (\%)), body mass index (BMI) in $\mathrm{Kg} / \mathrm{m} 2$, location, extent and duration of the disease, ongoing treatments, history of surgical resection, cumulative corticosteroid dose (expressed in g prednisone equivalent) and duration of corticosteroid treatment. Informed consent was obtained from all participants.

\subsection{Methods}

\subsubsection{Biochemical Markers}

Blood and urine samples were collected from all IBD patients and control subjects in the morning after an overnight fast. Then, they were stored at $-80^{\circ} \mathrm{C}$ until assayed. Calcium, phosphorus, total serum alkaline phosphate and creatinine were determined with an optimized method using a CX9 Beckmann Coulter automate. Urinary CrossLaps were measured with an immunoenzymatic method.

Serum intact parathyroid hormone (PTH), 25 hydroxy vitamin D $(25(\mathrm{OH}) \mathrm{D})$ and serum osteocalcin were measured by an electro-chemiluminescence immunoassay ECLIA (Roche Elecsys2010).

Laboratory parameters such as albumin and Erythrocyte Sedimentation Rate (ESR) were also checked in all patients.

The serum calcium was corrected with albumin level using this formula:

Corrected calcium level $=$ measured calcium level $+0,025$ x (40-albumin).

Table 1 shows the biochemical markers which were measured in IBD patients and controls, their analytical method, their normal range and their unit.

Table 1. Biochemical markers measured in Inflammatory Bowel Disease patients and controls, their analytical Method, their normal range and their unit.

\begin{tabular}{|c|c|c|c|}
\hline Biochemical Markers & Analytical Method & Normal Range & Unit \\
\hline Calcium & Colorimetric Arsenazo [13] & $2,2-2,6[13]$ & $\mathrm{mmol} / 1$ \\
\hline Phosphorus & Colorimetric phosphomolybdate complex [14] & $0,5-2[14]$ & $\mathrm{mmol} / 1$ \\
\hline Alcaline phosphatase & Kinetic rate method [15] & $38-126[15]$ & $\mathrm{UI} / \mathrm{L}$ \\
\hline Creatinine & Jaffe method [16] & $\begin{array}{c}\text { Male (70-120) } \\
\text { Female }(60-110)[16]\end{array}$ & $\begin{array}{c}\text { Male }=\text { age } / 2 \\
\text { Female }=\text { age }+10 / 2\end{array}$ \\
\hline Erythrocyte sedimentation rate & Wintrobe method & $\geq 30[17-20]$ & $\mathrm{mm}$ \\
\hline 25-OH Vitamin D & Electro-chimiluminescence immunoassy ECLIA [17] & $\mathrm{ng} / \mathrm{ml}$ \\
\hline Parathyroid hormone & Electro-chimiluminescence immunoassy ECLIA [21] & $15-65[21]$ & $\mathrm{pg} / \mathrm{ml}$ \\
\hline
\end{tabular}


(Table 1) contd.....

\begin{tabular}{|c|c|c|c|}
\hline Biochemical Markers & Analytical Method & Normal Range & Unit \\
\hline Serum osteocalcin & Electro-chimiluminescence immunoassy ECLIA [22] & \begin{tabular}{|c|} 
Female: \\
Premenopausal female: $11-43$ \\
Menopausal female: $15-46$ \\
Osteoporotic: $13-48$ \\
Male: \\
18 à < 30 years: 24 à 70 \\
30 à 50 years: 14 à 42 \\
$>50$ à 70 years: 14 à $46[22]$
\end{tabular} & $\mathrm{ng} / \mathrm{ml}$ \\
\hline Urinary Cross Laps & ELISA immunoassay [23] & $\begin{array}{c}\text { Menopausal female: } 67-544 \\
\text { Premenopausal female: } 121-874 \\
\text { Male: } 54-559 \text { [23] }\end{array}$ & $\mu \mathrm{g} / \mathrm{mmol}$ urinary creatinine \\
\hline Albumin & $\begin{array}{c}\text { Colorimetric bichromatic } \\
\text { digital endpoint methodology [24] }\end{array}$ & $34-48[24]$ & $\mathrm{g} / 1$ \\
\hline
\end{tabular}

Table 2. Study population demographic and clinical parameters.

\begin{tabular}{|c|c|c|c|}
\hline Parameters & IBD Group & Control Group & $\mathbf{p}$ \\
\hline Number $\mathrm{N}$ & 40 & 32 & \\
\hline Mean age (years) & $\begin{array}{c}43.53 \pm 13.96 \\
(16-71)\end{array}$ & $\begin{array}{c}44.72 \pm 14.12 \\
(16-70)\end{array}$ & $0.721^{\natural}$ \\
\hline $\begin{array}{l}\text { Sex }(\%) \\
\text { Female } \\
\text { Male }\end{array}$ & $\begin{array}{l}23(57.5 \%) \\
17(42.5 \%)\end{array}$ & $\begin{array}{l}15(46.8 \%) \\
17(53.2 \%)\end{array}$ & $0.255^{*}$ \\
\hline Current smokers (\%) & $12(30 \%)$ & $7(22 \%)$ & $0.3^{¥}$ \\
\hline Mean Solar Index & $\begin{array}{l}0.59 \pm 0,16 \\
(0.31-0.71)\end{array}$ & $\begin{array}{l}0.61 \pm 0,25 \\
(0.31-1.26)\end{array}$ & $0.628^{\natural}$ \\
\hline $\begin{array}{c}\text { Physical activity (\%) } \\
\text { Moderate activity } \\
\text { Sedentariness }\end{array}$ & $\begin{array}{l}23(57.5 \%) \\
17(42.5 \%)\end{array}$ & $\begin{array}{c}28(87.5 \%) \\
4(12.5 \%)\end{array}$ & $0.23^{*}$ \\
\hline Menopausal women (\%) & $14(34.8 \%)$ & $13(40 \%)$ & $0.65^{*}$ \\
\hline Duration of menopause(years) & $\begin{array}{c}7.75 \pm 6.8 \\
(1-20) \\
\end{array}$ & $\begin{array}{c}9.6 \pm 6.8 \\
(2-18)\end{array}$ & 0.599 \\
\hline Mean BMI $\left(\mathrm{kg} / \mathrm{m}^{2}\right)$ & $\begin{array}{c}20.98 \pm 3.59 \\
(13,84-32,81)\end{array}$ & $\begin{array}{c}25.05 \pm 3.96 \\
(17,11-32,41)\end{array}$ & $0.001^{\pi}$ \\
\hline
\end{tabular}

'Student - test; ${ }^{*}$ Chi-squared test. IBD: Inflammatory Bowel Disease; BMI: Body Mass Index

\subsubsection{Bone Mineral Density Measurements}

BMD was evaluated at the lumbar spine (L1 to L4) and the femoral neck using the Lunar Prodigy Dual-energy X-ray Absorptiometry (DXA) system.

BMD results were expressed as T-scores which is the number of Standard Deviations (SD) of the patients BMD from the mean peak value for a reference population with the same sex and race. Patients were classified according to the World Health Organisation (WHO) criteria [25] as normal (T-score > $-1 \mathrm{SD}$ at both lumbar spine and femoral neck), osteopenic (Tscore from -1.0 SD to $-2.5 \mathrm{SD}$ at either lumbar spine or femoral neck or both) and osteoporotic (T-score $\leq-2.5$ at either lumbar spine or femoral neck or both).

\subsubsection{Statistical Analysis}

Statistical analysis was carried out using the Statistical Package for Social Science (SPSS) program for Windows ${ }^{\circledR}$ version 20.0 software. Data were presented as the number (\%) and mean \pm Standard Deviation (SD) or median (range: min max). Differences between groups were compared by Student test for continuous variables or Mann-Whitney test (nonparametric test) and by Chi-squared test for categorical variables.
Correlations between continuous variables were assessed using Spearman rank correlation. A $p$ value $<0.05$ was considered statistically significant.

All authors had access to the study data and reviewed and approved the final manuscript.

\section{RESULTS}

The main characteristics of the study subjects are shown in Table 2.

In all, 40 Tunisian IBD patients and 32 age- and sexmatched healthy controls were enrolled in the study. No participants had a History of drug use related to bone density such as bisphosphonate, vitamin D 3, SERM, denosumab and statin.

Nineteen $(47.5 \%)$ patients were identified as having CD and $21(52.5 \%)$ patients as having UC.

There were 17 men and 23 women in the total group. In patients with $\mathrm{CD}$, male to female ratio was 0.72 and in UC patients, it was 0.75 . Mean age was $43.53 \pm 13.96$ years (range $16-71)$ in all IBD patients whereas it was $45.14 \pm 13.52$ years (range $16-71$ ) and $41.74 \pm 14.59$ years (range $19-62$ ) in UC and $\mathrm{CD}$ patients, respectively. 
There was no statistically significant difference in age, sex, smoking, solar index, physical activity and menopausal status between the IBD and the control groups. BMI was significantly lower in patients than controls subjects $(\mathrm{p}=0.001)$.

Median disease duration was 18 months (range $1-312$ months) for CD and 31 months (range $1-168$ months) for UC. $\mathrm{CD}$ was ileal in $15.8 \%$ of patients, ileocolonic in $68.4 \%$ and colonic in $15.8 \%$. For UC, $33.3 \%$ of patients had left sided colitis, $42.9 \%$ had pancolitis and $23.8 \%$ proctitis. Mild and moderate activities of the disease were observed in $73.68 \%$ and in $80.9 \%$ of the $\mathrm{CD}$ and $\mathrm{UC}$ patients, respectively. Intestinal resection had been performed in $26.31 \%$ of patients with $\mathrm{CD}$ and one patient with UC had undergone coloproctectomy with ileoanal anastomosis.

Twenty-two (19 CD and $3 \mathrm{UC}$ ) patients had received corticosteroid treatments. The cumulative dose was $3770 \pm$ $1081 \mathrm{mg}$.

Ten patients had received 5-aminosalicylic acid (5-ASA), eight patients azathioprine, one cyclosporine and three infliximab. The results of biochemical markers measured in both groups of patients and controls, and the mean levels are summarized in Table $\mathbf{3}$.

Mean calcium, phosphorus and alkaline phosphatase levels were similar in both groups. Median 25-hydroxyvitamin D levels were significantly lower in IBD patients compared with controls $(\mathrm{p}=0.0001)$.

Median serum osteocalcin levels were lower and median parathyroid hormone levels were higher in IBD patients compared with the control group but the differences did not reach statistical significance $(p=0.34$ and $p=0.187$ respectively).

Median urinary Cross Laps levels were significantly higher in IBD patients compared with healthy controls $(p=0.007)$.

During the follow-up period, none of the patients reported a history or symptoms of bone fracture.

The Median SD of femoral neck and lumbar spine T-scores in IBD patients were $-1(-3.2 ;-1.4)$ and $-1.65(-4 ;-1.5)$.
Using the WHO's diagnostic criteria, 12 (30\%) IBD patients were classified as normal, $13(32.5 \%)$ were osteopenic and $15(37.5 \%)$ were classified as osteoporotic.

Among controls, 20 subjects (62.5\%) had normal BMD, 11 subjects (34.4\%) had osteopenia and only one subject had osteoporosis.

Osteoporosis was more frequent in IBD patients than controls $(\mathrm{p}=0.0001)$.

No significant difference between UC and CD patients concerning the prevalence of osteopenia or osteoporosis was found $(\mathrm{p}=0.828)$.

Mean age of patients with low BMD $(46.42 \pm 14.33$ years $)$ was significantly higher compared with those with normal BMD $(39.75 \pm 10.42)(p=0.001)$. Fifteen patients had osteoporosis: ten men and five women. The prevalence of osteoporosis was significantly higher in men than women ( $p=$ $0.05)$.

There was no correlation between disease duration and disease clinical activity or disease localization and low BMD. Mean serum level of ESR was significantly higher in IBD patients with low BMD compared with IBD patients with normal BMD $(p=0.039)$. There was no significant correlation between low BMD and 25-OH vitamin D levels or urinary Cross Laps levels.

Among the twenty-eight patients who had low BMD, 16 had received corticosteroids and 12 did not. In the normal BMD group, 6 had received corticosteroid and 6 did not. The percentage of IBD patients who had received corticosteroid was numerically higher in the low BMD group compared with the normal BMD group but the difference was not statistically significant. The median cumulative dose of corticosteroid in patients with low BMD $(515 \mathrm{mg}(0-11200 \mathrm{mg}))$ was higher compared with those with normal BMD (250 mg (0 - 23900 $\mathrm{mg}$ ) but the difference was not statistically significant ( $\mathrm{p}=$ 0.642 ).

Table 4 shows the risk factors associated with low BMD in IBD patients.

Table 3. Bone biochemical markers and bone mineral density in the two groups of patients and controls.

\begin{tabular}{|c|c|c|c|}
\hline Biochemical Markers & $\begin{array}{l}\text { IBD Patients } \\
(\mathrm{n}=40)\end{array}$ & $\begin{array}{l}\text { Control } \\
(\mathrm{n}=32)\end{array}$ & $\mathbf{p}$ \\
\hline Calcium $(\mathrm{mmol} / \mathrm{l})^{*}$ & $2.43 \pm 0.13$ & $2.42 \pm 0.10$ & $0.730^{\circ}$ \\
\hline Phosphorus (mmol/l)* & $1.22 \pm 0.21$ & $1.13 \pm 0.20$ & $0.060^{\natural}$ \\
\hline Alcaline phosphatase (UI/l)* & $101.25 \pm 44.10$ & $88.75 \pm 44.18$ & $0.230^{\circ}$ \\
\hline $\begin{array}{c}25-\mathrm{OH} \text { Vitamin } \mathrm{D} \\
(\mathrm{ng} / \mathrm{ml})^{* *}\end{array}$ & $3.14(3-36.68)$ & $9.03(3-41.74)$ & $0.0001^{*}$ \\
\hline PTH $(\mathrm{pg} / \mathrm{ml}) * *$ & $47.04(23.37-223.4)$ & $41.57(22.08-83.32)$ & $0.187^{*}$ \\
\hline $\begin{array}{l}\text { Serum osteocalcin } \\
(\mathrm{ng} / \mathrm{ml}) * *\end{array}$ & $22.36(8.08-60.48)$ & $24.6(10.66-165.6)$ & $0.340^{*}$ \\
\hline $\begin{array}{c}\text { Urinary CTX } \\
(\mu \mathrm{g} / \mathrm{mmol} \text { de créatinurie }) * *\end{array}$ & $465.06(28.02-876.62)$ & $343.29(37.77-1323.53)$ & $0.007^{*}$ \\
\hline Osteopenia(\%) & $13(32.5 \%)$ & $11(34.4 \%)$ & $0.45^{\mathfrak{\varepsilon}}$ \\
\hline Osteoporosis(\%) & $15(37.5 \%)$ & $1(3 \%)$ & $0.001^{£}$ \\
\hline
\end{tabular}

* Mean concentration; **Median concentration; ๆ Student t- Test; ¥ U- Mann-Whitney test. £Chi-squared test PTH: Parathyroid hormone; CTX: Cross Laps 
Table 4. Risk factors associated with low BMD in the IBD patients.

\begin{tabular}{|c|c|c|c|c|}
\hline Risk Factors & Low BMD & Normal BMD & Control Group & $\mathbf{p}$ \\
\hline $\begin{array}{c}\text { Gender: } \\
\text { Male: N (\%) } \\
\text { Female: N (\%) }\end{array}$ & $\begin{array}{l}13(32.5) \\
15(37.5)\end{array}$ & $\begin{array}{l}4(10) \\
8(20)\end{array}$ & $\begin{array}{l}15(47) \\
17(53)\end{array}$ & $\mathrm{NS}^{\S}$ \\
\hline Age (years)* & $46.42 \pm 14.33$ & $39.75 \pm 10.42$ & $44,72 \pm 14,12$ & $\mathrm{NS}$ \\
\hline $\operatorname{BMI}\left(\mathrm{kg} / \mathrm{m}^{2}\right)^{*}$ & $20.71 \pm 3.06$ & $21.52 \pm 4.59$ & $25.05 \pm 3,96$ & 0.001 ॠ \\
\hline $\begin{array}{l}\text { Type of IBD: } \\
\text { CD: N (\%) } \\
\text { UC: N }(\%)\end{array}$ & $\begin{array}{l}14(35) \\
14(35)\end{array}$ & $\begin{array}{l}5(12.5) \\
7(17.5)\end{array}$ & & $\mathrm{NS}^{\S}$ \\
\hline IBD duration (months)* & $58.41 \pm 86.23$ & $45.92 \pm 54.75$ & & $\mathrm{NS}^{¥}$ \\
\hline $\begin{array}{c}\text { Corticosteroids: } \\
\text { Yes: N }(\%) \\
\text { No: N }(\%)\end{array}$ & $\begin{array}{l}16(40) \\
12(30)\end{array}$ & $\begin{array}{l}6(15) \\
6(15)\end{array}$ & 0 & $\mathrm{NS}^{\S}$ \\
\hline Cumulative dose of steroids $(\mathrm{mg})^{* *}$ & $515(0-11200)$ & $250(0-23900)$ & 0 & $\mathrm{NS}^{¥}$ \\
\hline $\begin{array}{c}\text { Bowel surgery: } \\
\text { Yes: N }(\%) \\
\text { No: N }(\%)\end{array}$ & $\begin{array}{c}2(5) \\
24(60)\end{array}$ & $\begin{array}{c}4(10) \\
10(25)\end{array}$ & 0 & $\mathrm{NS}^{\S}$ \\
\hline $\begin{array}{l}\text { Disease localization (CD): Colonic: N (\%) } \\
\text { Ileocolonic + ileal: N (\%) }\end{array}$ & $\begin{array}{c}2(10.5) \\
12(63.2)\end{array}$ & $\begin{array}{c}0 \\
5(26.3)\end{array}$ & & $\mathrm{NS}^{\S}$ \\
\hline $\begin{array}{l}\text { Disease localization (UC): Proctitis: N (\%) } \\
\text { Left side colitis+pancolitis: N (\%) }\end{array}$ & $\begin{array}{c}3(14.3) \\
11(52.4)\end{array}$ & $\begin{array}{l}2(9.5) \\
5(23.8)\end{array}$ & & $\mathrm{NS}^{\S}$ \\
\hline $\mathrm{ESR}^{*}$ & $49 \pm 15.67$ & $31.8 \pm 13.1$ & 10 & $0.039^{\pi}$ \\
\hline Calcium $(\mathrm{mmol} / 1)^{*}$ & $2.43 \pm 0.11$ & $2.42 \pm 0.16$ & $2,42 \pm 0,10$ & $\mathrm{NS}^{\pi}$ \\
\hline Phosphorus (mmol/l)* & $1.22 \pm 0.19$ & $1.23 \pm 0.25$ & $1,13 \pm 0,20$ & $\mathrm{NS}{ }^{\pi}$ \\
\hline Alcaline phosphatase (UI/L)* & $108.12 \pm 45.26$ & $89.8 \pm 41$ & $88,75 \pm 44,18$ & $\mathrm{NS}{ }^{\pi}$ \\
\hline $25-\mathrm{OH}$ vitamin $\mathrm{D}(\mathrm{ng} / \mathrm{ml})^{* *}$ & 3,65 & 3 & 9.03 & $0.009^{*}$ \\
\hline $\mathrm{PTH}(\mathrm{pg} / \mathrm{ml}) * *$ & 42.11 & 55.4 & 41.57 & $\mathrm{NS}^{¥}$ \\
\hline Serum osteocalcin $(\mathrm{ng} / \mathrm{ml}) * *$ & 28.74 & 18.51 & 24.6 & $\mathrm{NS}^{¥}$ \\
\hline Urinairy CTX $(\mu \mathrm{g} / \mathrm{mmol} \text { urinary creatinine })^{* *}$ & 541.58 & 358.15 & 343.3 & $\mathrm{NS}^{¥}$ \\
\hline Fractures $(\%)$ & 0 & 0 & 0 & $\mathrm{NS}^{\S}$ \\
\hline
\end{tabular}

* Mean value; **Median value; ๆ Student t- Test; ¥ U- Mann-Whitney test; § Chi-squared test. N: number; BMD: Bone Mineral Density; BMI: Body Mass Index; IBD: inflammatory bowel disease; CD: Crohn's Disease; UC: Ulcerative Colitis; ESR: Erythrocyte Sedimentation Rate; PTH: parathyroid hormone; CTX: Cross Laps; NS: not significant

\section{DISCUSSION}

In this study, we found that $70 \%$ of Tunisian patients with IBD have low BMD. The prevalence of osteopenia and osteoporosis was $32.5 \%$ and $37.5 \%$ respectively. We found a high prevalence of low BMD in our patients, which is considered to be one of the highest prevalence rates among previously-published articles. The prevalence of low BMD has been reported in the range of $22-77 \%$ in some earlier studies [26 - 32].

The prevalence of osteoporosis (37.5\%) in our cohort of Tunisian IBD patients is comparable with that reported in other studies (12-57\%) [14 - 20]. Moreover, the proportion of IBD patients with osteopenia was $32.5 \%$ which is comparable with the corresponding value reported from other studies $23-67 \%$ [14 - 20]. Osteoporosis is typically a multifactorial disease. The pathogenic mechanisms that might contribute to low BMD in IBD patients include advancing age, low BMI, smoking, alcohol abuse, immobilization or inactive lifestyle, the activation of inflammatory cytokines, hypogonadism, malnutrition, intestinal malabsorption of calcium and vitamin $\mathrm{D}$, the use of corticosteroids, and genetic susceptibility $[4,33]$.

No significant difference between CD and UC was found.
Several studies have failed to demonstrate any difference in the prevalence of bone loss between CD and UC [26, 28, 34, 35]. Other studies reported lower BMD in CD compared with UC $[6,27,36]$.

Equally important is that this study the high prevalence of low BMD in male patients as compared with females. In agreement with some studies by Jahnsen et al., Robinson et al. and Shirazi et al. in the 2 patients groups studied (CD and UC), men had lower BMD than women [1, 5, 37].

There is evidence that body mass affects bone density in IBD. Several studies have shown that BMI is correlated with BMD [3, 30, 32, 38, 39]. Our present study did not found any correlation between BMI and low BMD.

Prior investigators have speculated controversies regarding the features of low BMD and corticosteroid use in IBD patients. In some of these studies, corticosteroid therapy appeared as a risk factor of bone loss [27, 29, 30, 40, 41]. Frei et al. [30] demonstrated that bone loss is associated with cumulative steroid dose and duration of treatment. The main mechanism by which corticosteroids induce BMD loss is impairing osteoblast function, inducing osteoblast apoptosis, reducing intestinal calcium absorption and increasing renal 
calcium excretion $[42,43]$.

Unlike other studies, corticosteroid treatment is not associated with low BMD [3, 44, 45]. In the present study, we showed a significant association between duration of treatment and not with cumulative steroid dose.

There is controversial data in the literature regarding bowel resection as a risk factor of low BMD. Von Tirpitiz et al. found that history of bowel resection is a significant predictive factor of low BMD [46]. In our present work, in accordance with Silvennoien et al. [35] and Stockbrugger et al. [47], this correlation could not be found.

Vitamin D deficiency and disturbances of calcium metabolism would be a contributing factor to bone loss in IBD [48]. A review on vitamin D status in IBD reported hypovitaminosis D in up to $65 \%$ of adult patients [49]. Several reasons have been suggested for the low vitamin D status in patients with IBD including reduced intestinal absorption of vitamin $\mathrm{D}$ as a consequence of ileopathy, disrupted enterohepatic circulation of this vitamin, renal insufficiency and reduced dietary intake and exposure to sunshine [50]. In this study, 25 OHD levels were significantly low in IBD patients compared with controls but were not associated with osteoporosis. Thus, vitamin D deficiency is not the main cause of low BMD in most IBD patients. Moreover, PTH concentrations were higher compared with controls but didn't reach a significant difference. These results are in accordance with those of Robinson [51], Silvennoinen [52] and Haj Taeib [53].

Characterization of bone turnover is useful as previous data showed that biochemical markers of bone metabolism may help to estimate the risk of rapid bone loss, to choose and monitor therapeutic intervention, and to predict long-term osteodensitometric response to therapy $[54,55]$.

Previous studies using biochemical bone markers in IBD have produced conflicting results, showing either increased bone resorption without a compensatory increase in bone formation including our study $[26,35,56]$, decreased bone formation with no variation in resorptive markers $[34,57,58]$, decreased [59] or increased [27, 50, 60, 61] both bone formation and resorption markers. We showed an increase in bone resorption with no variation in bone formation as Haj Taeib and al [53] did.

In conclusion, this work can be considered as a warning about the importance of investigating bone changes in IBD patients. Our data set has demonstrated that patients with IBD have a high risk of osteoporosis. Major risk factors for low BMD values were age, inflammation biological marker and duration of corticosteroid treatment. Screening of these patients regularly and supplementation with vitamin D and/or Calcium could prevent osteoporotic process and its complications.

A limitation of our current study might be the restricted population of IBD patients, which needs to be further evaluated in a large cohort of patients. On the other hand, it is interesting to investigate the effect of substitution therapy in these patients by the monitoring of the BMD under treatment.

\section{CONCLUSION}

Bone alteration is more frequent in patients with IBD compared with healthy controls whereas there is no difference, concerning BMD, between CD and UC patients. In addition, we showed that serum levels of vitamin $\mathrm{D}$ were lower in the IBD group and urinary CrossLaps levels were higher. We also found that Low BMI and hypovitaminoses D in IBD patients due to malabsorption are risk factors for low BMD.

Finally, this study is a warning about the importance of monitoring of BMD by DEXA scan in patients with IBD in the clinical practice. Screening of these patients and starting initiating appropriate treatment could prevent bone loss and its complications especially among at-risk patients.

\section{LIST OF ABBREVIATIONS}

$\begin{array}{lll}\text { IBD } & =\text { Inflammatory Bowel Disease } \\ \text { 25(OH) D } & =\text { 25-hydroxy vitamin D } \\ \text { PTH } & =\text { Parathyroid Hormone } \\ \text { OC } & =\text { Osteocalcin } \\ \text { CTX I } & =\text { C-terminal telopeptide of type I collagen } \\ \text { BMD } & =\text { Bone Mineral Density } \\ \text { CD } & =\text { Crohn's Disease } \\ \text { UC } & =\text { Ulcerative Colitis } \\ \text { CDAI } & =\text { Crohn's Disease Activity Index } \\ \text { BMI } & =\text { Body Mass Index } \\ \text { ESR } & =\text { Erythrocyte Sedimentation Rate } \\ \text { DXA } & =\text { X-ray Absorptiometry } \\ \text { WHO } & =\text { World Health Organisation } \\ \text { SD } & =\text { Standard Deviations } \\ \text { 5-ASA } & =\text { 5-Aminosalicylic Acid }\end{array}$

ETHICS APPROVAL AND CONSENT TO PARTICIPATE

The study received research ethics board approval from the "C.P.P.SUD” (0069/2018) committee.

\section{HUMAN AND ANIMAL RIGHTS}

No Animals were used in this research. All human research procedures followed were in accordance with the ethical standards of the committee responsible for human experimentation (institutional and national), and with the Helsinki Declaration of 1975, as revised in 2013.

\section{CONSENT FOR PUBLICATION}

Informed consent was obtained from all participants.

\section{CONFLICT OF INTEREST}

The authors declare no conflict of interest, financial or otherwise.

\section{ACKNOWLEDGEMENTS}

Samar BEN JEMAA, Lassaad CHTOUROU, Rim AKROUT, Hela MAKNI FOURATI, Ali AMOURI, Nabil TAHRI and Sofien BAKLOUTI contributed to conception, 
design, acquisition, and interpretation of data. Khansa CHAABOUNI, Tarek CHAABOUNI and Fatma AYEDI contributed to data analysis.

\section{REFERENCES}

[1] Robinson RJ, al-Azzawi F, Iqbal SJ, et al. Osteoporosis and determinants of bone density in patients with Crohn's disease. Dig Dis Sci 1998; 43(11): 2500-6.

[http://dx.doi.org/10.1023/A:1026650719552] [PMID: 9824142]

[2] Ananthakrishnan AN, McGinley EL, Binion DG, Saeian K. Fractureassociated hospitalizations in patients with inflammatory bowel disease. Dig Dis Sci 2011; 56(1): 176-82.

[http://dx.doi.org/10.1007/s10620-010-1433-9] [PMID: 20936351]

[3] Boubaker J, Feki M, Hsairi M, et al. Osteoporosis and inflammatory bowel disease: Prevalence and risk factors in Tunisian patients. Gastroenterol Clin Biol 2003; 27(10): 901-7.

[PMID: 14631305]

[4] Kotze LM, Costa CT, Cavassani MF, Nisihara RM. Alert for bone alterations and low serum concentrations of vitamin $\mathrm{D}$ in patients with intestinal inflammatory disease. Rev Assoc Med Bras (1992) 2017; 63(1): 13-7.

[http://dx.doi.org/10.1590/1806-9282.63.01.13] [PMID: 28225873]

[5] Jahnsen J, Falch JA, Aadland E, Mowinckel P. Bone mineral density is reduced in patients with Crohn's disease but not in patients with ulcerative colitis: A population based study. Gut 1997; 40(3): 313-9. [http://dx.doi.org/10.1136/gut.40.3.313] [PMID: 9135518]

[6] Bregenzer N, Erban P, Albrich H, et al. Screening for osteoporosis in patients with inflammatory bowel disease by using urinary $\mathrm{N}$ telopeptides. Eur J Gastroenterol Hepatol 2002; 14(6): 599-605. [http://dx.doi.org/10.1097/00042737-200206000-00004] [PMID: 12072593]

[7] Schoon EJ, Blok BM, Geerling BJ, Russel MG, Stockbrügger RW, Brummer RJ. Bone mineral density in patients with recently diagnosed inflammatory bowel disease. Gastroenterology 2000; 119(5): 1203-8. [http://dx.doi.org/10.1053/gast.2000.19280] [PMID: 11054377]

[8] Stange EF, Travis SPL, Vermeire S, et al. European Crohn's and Colitis Organisation (ECCO). European evidence-based Consensus on the diagnosis and management of ulcerative colitis: Definitions and diagnosis. J Crohn's Colitis 2008; 2(1): 1-23.

[http://dx.doi.org/10.1016/j.crohns.2007.11.001] [PMID: 21172194]

[9] Stange EF, Travis SPL, Vermeire S, Beglinger C, Kupcinskas L. K Geboes and al. European crohn's and colitis organisation. European evidence based consensus on the diagnosis and management of Crohn's disease: Definitions and diagnosis. Gut 2006; 55: 1-15. [http://dx.doi.org/10.1136/gut.2005.081950a] [PMID: 16344569]

[10] Satsangi J, Silverberg MS, Vermeire S, Colombel J-F. The Montreal classification of inflammatory bowel disease: Controversies, consensus, and implications. Gut 2006; 55(6): 749-53.

[http://dx.doi.org/10.1136/gut.2005.082909] [PMID: 16698746]

[11] Truelove SC, Witts LJ. Cortisone in ulcerative colitis. BMJ 1955; 2(4947): 1041-8.

[http://dx.doi.org/10.1136/bmj.2.4947.1041] [PMID: 13260656]

[12] Best WR, Becktel JM, Singleton JW, Kern F Jr. Development of a crohn's disease activity index. National cooperative crohn's disease study. Gastroenterology 1976; 70(3): 439-44. [PMID: 1248701]

[13] Reactive Brochures. Calcium Beckman Coulter. Mode d'emploi 2007 DECEMBRE; 389721 AD

[14] Reactive Brochures. Phosphorus Beckman Coulter. Chemistry Information Sheet $2008 \mathrm{MARCH} ; 389789 \mathrm{AF}$

[15] Reactive Brochures. Alkaline phosphatase Beckman Coulter. Chemistry Information Sheet 2015 DECEMBER; A18450 AN

[16] Reactive Brochures. Creatinine Beckman Coulter. Chemistry Information Sheet 2015 DECEMBER; A44573 AL

[17] Reactive Brochures. $\operatorname{ELECSYS}^{\circledR}$ vitamin D assay. Electrochemiluminescence binding assay (ECLIA) for the in-vitro determination of total 25-hydroxyvitamin D. Roche Diagnostics 2016.

[18] Souberbielle JC, Prié D, Courbebaisse M, et al. Actualité sur les effets de la vitamine $\mathrm{D}$ et l'évaluation du statut vitaminique $\mathrm{D}$. Revue Francophone des laboratoires 2009; 414: 31-9.

[19] Haroon M, Regan MJ. Vitamin D deficiency: The time to ignore it has passed. Int J Rheu Dis 2010; 13 318Ŕ323

[20] De jaeger C, Cherin P. Vitamine D: Effets sur la santé. Recommandations de bon usage. Médecine et Longévité 2010; 2: 182-99.
[21] Reactive Brochures. PTH Ref 11972103 122.Roche Diagnostics GmbH. D-68298 Mannheim. 2015-03, V 24.0 English

[22] Reactive Brochures. N-MID Osteocalcin Ref 12149133 122. Elecsys 1010/2010 e MODULAR ANALYTICS E170.

[23] Reactive Brochures. Urine Cross Laps ${ }^{\circledR}$ EIA. For the quantification of degradation products of C-terminal telopeptides of Type 1 collagen in human urine. 2010; Doc: AC-03PL-A(4)

[24] Reactive Brochures. Albumin Beckman Coulter. Chemistry Information Sheet A18449AL 2015 APRIL;

[25] World Health Organisation. Assessment of fracture risk and its application to sceening for post-menopausal osteoporosis. Report of a WHO study group. Tech Rep Ser (World Health Organ) 1994; 843: $1-129$.

[26] Bjarnason I, Macpherson A, Mackintosh C, Buxton-Thomas M, Forgacs I, Moniz C. Reduced bone density in patients with inflammatory bowel disease. Gut 1997; 40(2): 228-33. [http://dx.doi.org/10.1136/gut.40.2.228] [PMID: 9071937]

[27] Ardizzone S, Bollani S, Bettica P, Bevilacqua M, Molteni P, Bianchi Porro G. Altered bone metabolism in inflammatory bowel disease: There is a difference between Crohn's disease and ulcerative colitis. J Intern Med 2000; 247(1): 63-70.

[http://dx.doi.org/10.1046/j.1365-2796.2000.00582.x]

[PMID: 10672132]

[28] Pollak RD, Karmeli F, Eliakim R, Ackerman Z, Tabb K, Rachmilewitz D. Femoral neck osteopenia in patients with inflammatory bowel disease. Am J Gastroenterol 1998; 93(9): 1483-90.

[http://dx.doi.org/10.1111/j.1572-0241.1998.468_q.x] [PMID: 9732930]

[29] Sahli H, Meddeb N, Landolsi F. Fekih Monia, Boubaker Jalel, Filal Azza and al. Ostéoporose et maladie de crohn. Rev Rhum 2005; 72 : $820-4$.

[30] Frei P, Fried M, Hungerbuhler V, Rammert C, Rousson V, KullakUblick GA. Analysis of risk factors for low bone mineral density in inflammatory bowel disease. Digestion 2006; 73(1): 40-6.

[http://dx.doi.org/10.1159/000092013] [PMID: 16543736]

[31] Koutroubakis IE, Zavos C, Damilakis J, et al. Low bone mineral density in Greek patients with inflammatory bowel disease: Prevalence and risk factors. Ann Gastroenterol 2011; 24(1): 41-6. [PMID: 24714255]

32] Dumitrescu G, Mihai C, Dranga M, Prelipcean CC. Bone minera density in patients with inflammatory bowel disease from northeastern Romania. Rev Med Chir Soc Med Nat Iasi 2013; 117(1): 23-8. [PMID: 24505888]

[33] Abid H, Babakhouya F, Mellouki I, Aqodad N, Benajah D, El Abkari M. Prévalence de la perte osseuse au cours des maladies inflammatoires chroniques de l'intestin: Résultats préliminaires d'une étude mono-centrique marocaine. Revue marocaine des maladies de l'appareil digestif 2014; 17: 5-12.

[34] Tan B, Li P, Lv H, et al. Vitamin D levels and bone metabolism in Chinese adult patients with inflammatory bowel disease. J Dig Dis 2014; 15(3): 116-23

[http://dx.doi.org/10.1111/1751-2980.12118] [PMID: 24354597]

[35] Silvennoinen JA, Karttunen TJ, Niemelä SE, Manelius JJ, Lehtola JK. A controlled study of bone mineral density in patients with inflammatory bowel disease. Gut 1995; 37(1): 71-6. [http://dx.doi.org/10.1136/gut.37.1.71] [PMID: 7672685]

[36] Targownik LE, Bernstein CN, Nugent Z, Leslie WD. Inflammatory bowel disease has a small effect on bone mineral density and risk for osteoporosis. Clin Gastroenterol Hepatol 2013; 11(3): 278-85. [http://dx.doi.org/10.1016/j.cgh.2012.10.022] [PMID: 23103821]

[37] Shirazi KM, Somi MH, Rezaeifar P, Fattahi I, Khoshbaten M, Ahmadzadeh M. Bone density and bone metabolism in patients with inflammatory bowel disease. Saudi J Gastroenterol 2012; 18(4): 241-7. [http://dx.doi.org/10.4103/1319-3767.98428] [PMID: 22824766]

[38] Sakellariou GT, Moschos J, Berberidis C, Mpoumponaris A, Kadisc S. Molyvas E and al. Densité osseuse chez des hommes jeunes soufrant d'entérocolopathies inflammatoires récemment diagnostiquées. Rev Rhum 2006; 73: 1395-9.

[http://dx.doi.org/10.1016/j.rhum.2006.04.010]

[39] Jahnsen J, Falch JA, Mowinckel P, Aadland E. Body composition in patients with inflammatory bowel disease: A population-based study. Am J Gastroenterol 2003; 98(7): 1556-62.

[http://dx.doi.org/10.1111/j.1572-0241.2003.07520.x] [PMID: 12873577]

[40] Zali M, Bahari A, Firouzi F, et al. Bone mineral density in Iranian patients with inflammatory bowel disease. Int J Colorectal Dis 2006; 21(8): 758-66. 
[http://dx.doi.org/10.1007/s00384-005-0084-3] [PMID: 16463035]

[41] Siffledeen JS, Fedorak RN, Siminoski K, et al. Bones and Crohn's: Risk factors associated with low bone mineral density in patients with Crohn's disease. Inflamm Bowel Dis 2004; 10(3): 220-8. [http://dx.doi.org/10.1097/00054725-200405000-00007] [PMID: 15290915]

[42] van Staa TP, Leufkens HG, Abenhaim L, Zhang B, Cooper C. Oral corticosteroids and fracture risk: Relationship to daily and cumulative doses. Rheumatology (Oxford) 2000; 39(12): 1383-9.

[http://dx.doi.org/10.1093/rheumatology/39.12.1383] [PMID: 11136882]

[43] Ezzat Y, Hamdy K. The frequency of low bone mineral density and its associated risk factors in patients with inflammatory bowel diseases. Int J Rheum Dis 2010; 13(3): 259-65.

[http://dx.doi.org/10.1111/j.1756-185X.2010.01542.x] [PMID: 20704624]

[44] Habtezion A, Silverberg MS, Parkes R, Mikolainis S, Steinhart AH. Risk factors for low bone density in Crohn's disease. Inflamm Bowel Dis 2002; 8(2): 87-92.

[http://dx.doi.org/10.1097/00054725-200203000-00003] [PMID: 11854605]

[45] Ghosh S, Cowen S, Hannan WJ, Ferguson A. Low bone mineral density in Crohn's disease, but not in ulcerative colitis, at diagnosis. Gastroenterology 1994; 107(4): 1031-9.

[http://dx.doi.org/10.1016/0016-5085(94)90227-5] [PMID: 7926456]

[46] von Tirpitz C, Steder-Neukamm U, Glas K, et al. Osteoporosis in inflammatory bowel disease - Results of a survey among members of the German Crohn's and Ulcerative Colitis Association. Z Gastroenterol 2003; 41(12): 1145-50. [PMID: 14661123]

[47] Stockbrügger RW, Schoon EJ, Bollani S, et al. Discordance between the degree of osteopenia and the prevalence of spontaneous vertebral fractures in Crohn's disease. Aliment Pharmacol Ther 2002; 16(8): 1519-27.

[http://dx.doi.org/10.1046/j.1365-2036.2002.01317.x] [PMID: 12182752]

[48] Jahnsen J, Falch JA, Mowinckel P, Aadland E. Vitamin D status, parathyroid hormone and bone mineral density in patients with inflammatory bowel disease. Scand J Gastroenterol 2002; 37(2): $192-9$.

[http://dx.doi.org/10.1080/003655202753416876] [PMID: 11843057]

[49] Pappa HM, Grand RJ, Gordon CM. Report on the vitamin D status of adult and pediatric patients with inflammatory bowel disease and its significance for bone health and disease. Inflamm Bowel Dis 2006; 12(12): 1162-74.

[http://dx.doi.org/10.1097/01.mib.0000236929.74040.b0] [PMID: 17119391]

[50] McCarthy D, Duggan P, O'Brien M, et al. Seasonality of vitamin D status and bone turnover in patients with Crohn's disease. Aliment Pharmacol Ther 2005; 21(9): 1073-83. [http://dx.doi.org/10.1111/j.1365-2036.2005.02446.x]

[PMID: 15854168]

[51] Robinson RJ, Iqbal SJ, Abrams K, Al-Azzawi F, Mayberry JF. Increased bone resorption in patients with Crohn's disease. Aliment Pharmacol Ther 1998; 12(8): 699-705.

[http://dx.doi.org/10.1046/j.1365-2036.1998.00364.x]

[PMID: 9726381]

[52] Silvennoinen J. Relationships between vitamin D, parathyroid hormone and bone mineral density in inflammatory bowel disease. $\mathrm{J}$ Intern Med 1996; 239(2): 131-7.

[http://dx.doi.org/10.1046/j.1365-2796.1996.420765000.x] [PMID: 8568480]

[53] Hadj Taieb S, Kallel L, Feki M, et al. Unbalanced bone remodeling in Tunisian patients with inflammatory bowel diseases. Tunis Med 2013; 91(4): 273-7

[PMID: 23673708]

[54] Cashman KD. Altered bone metabolism in inflammatory disease: Role for nutrition. Proc Nutr Soc 2008; 67(2): 196-205. [http://dx.doi.org/10.1017/S0029665108007039] [PMID: 18412993]

[55] Watts NB. Clinical utility of biochemical markers of bone remodeling. Clin Chem 1999; 45(8 Pt 2): 1359-68. [PMID: 10430819]

[56] Gilman J, Shanahan F, Cashman KD. Altered levels of biochemical indices of bone turnover and bone-related vitamins in patients with Crohn's disease and ulcerative colitis. Aliment Pharmacol Ther 2006; 23(7): 1007-16.

[http://dx.doi.org/10.1111/j.1365-2036.2006.02835.x] [PMID: 16573803]

[57] Bischoff SC, Herrmann A, Göke M, Manns MP, von zur Mühlen A, Brabant G. Altered bone metabolism in inflammatory bowel disease. Am J Gastroenterol 1997; 92(7): 1157-63.

[PMID: 9219790]

[58] Schoon EJ, Geerling BG, Van Dooren IM, et al. Abnormal bone turnover in long-standing Crohn's disease in remission. Aliment Pharmacol Ther 2001; 15(6): 783-92.

[http://dx.doi.org/10.1046/j.1365-2036.2001.00997.x] [PMID: 11380316]

[59] Schulte C, Dignass AU, Mann K, Goebell H. Reduced bone mineral density and unbalanced bone metabolism in patients with inflammatory bowel disease. Inflamm Bowel Dis 1998; 4(4): 268-75. [http://dx.doi.org/10.1097/00054725-199811000-00002] [PMID: 9836078]

[60] Pollak RD, Karmeli F, Eliakim R, Acherman Z, Tabb K, Rachmilewitz D. Femoral neck osteopenia in patients with IBD. Am J Gastroenterol 1998; 93: 1483-90.

[http://dx.doi.org/10.1111/j.1572-0241.1998.468_q.x] [PMID: 9732930]

[61] Miheller P, Toth M, Molnar E, Zágoni T, Rácz K, Tulassay Z. Serum bone marker measurements in bone metabolism disorders associated with inflammatory bowel diseases. Orv Hetil 2001; 142: 1557-60.

\section{C) 2019 Ben Jemaa et al.}

This is an open access article distributed under the terms of the Creative Commons Attribution 4.0 International Public License (CC-BY 4.0), a copy of which is available at: (https://creativecommons.org/licenses/by/4.0/legalcode). This license permits unrestricted use, distribution, and reproduction in any medium, provided the original author and source are credited. 